\section{[127] 乘合自動車}

[特許第 117764 总・発明 者 藤伊越・(特許權者) 三

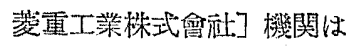
普通のもの小如〈前端中央 部に位せしめ、床 $a$ をシャ シーの全長に及べる一連の 矩形となし、機関の㖇側上 位には總て外向きの客䅉 $c$ を作つて、その下に開闒自 在の機関顬 $d$ を設けたも のでるる。林の面積を譄加 し、操縱及び俅動も都合よ く出来る。第8 図は平面図 第9図は側面図、筧 10 図 は本発眀の座店。(山柇)
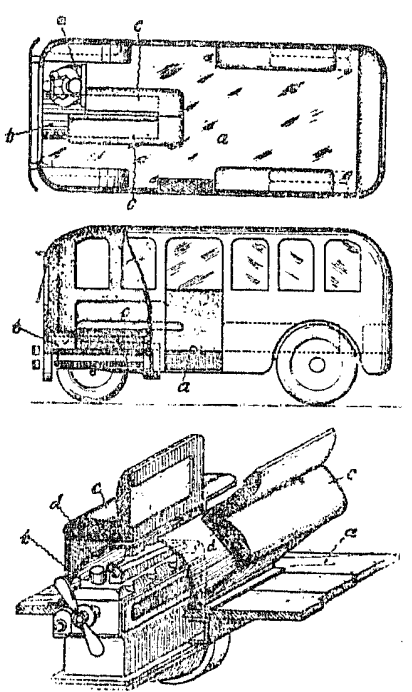

上上り 第 $8,9 ， 10$ 固。

[128] 切削力測定器

[特許第 117797 号・発明者 (特部權者) 石田䥊一] 工作 譏栈の工具 Iに作用する切剈力を湘定する器械の中で、测定 すべき力の大さを軽 減するため工具と力 の計浿裝置との間に 数個の频正子 $L_{1}, L_{2}$ を介在させ、叉力の 計澌裴置としては棒 材 2 の㹉れを利用す る方式は知的れてる る。本発明はこの種 のものに於て解子の 動きを四滑ならしめ るため、政于の接触 点に皿の中に数個の 鋼球老入れて接触点 の滑り犘擦を轉り磨 擦に变ずる装置 $b_{3}$

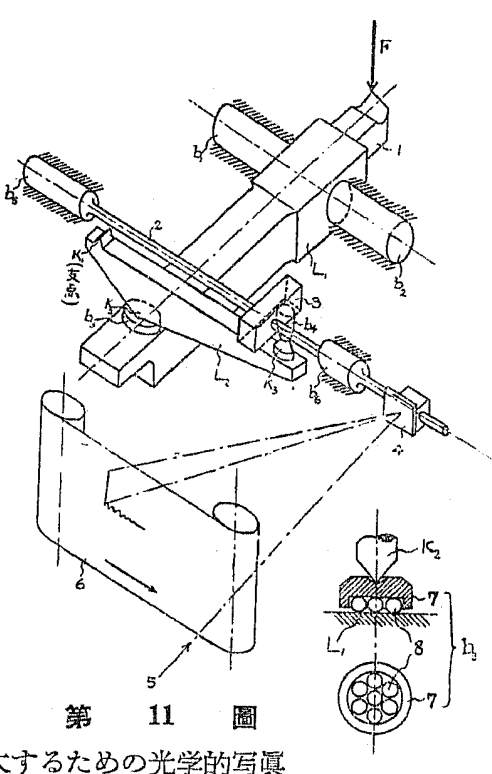

第 12 龽
と、棒材の㨝れを㩔大するための光学的写酎

裝置とを設けたものでする。第 11 図は概念

因、第 12 図は接蟲点の動きを円滑ならしめる装置。(山村)

\section{[129] 屈曲力測定裝置}

[特許第 117575 号・発明者 並河杽・(特許權者) 藤倉電

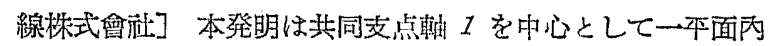

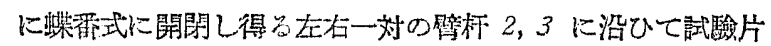

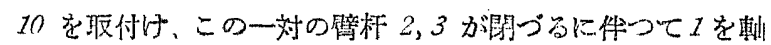

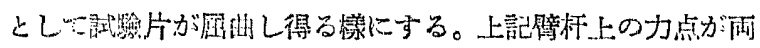

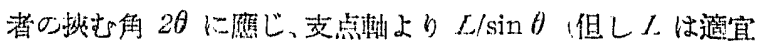

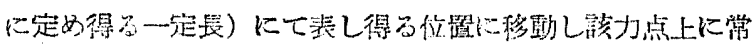

に一定方向に力 $2 F$ を加へる專により先右の臂杆に直的に

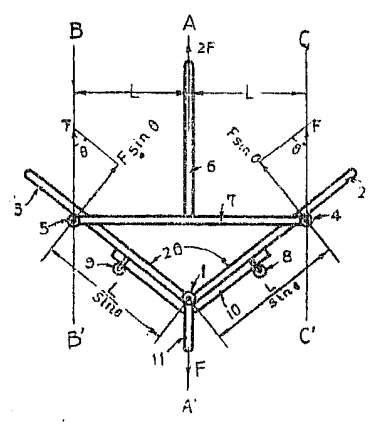

第 13 圆 してこれを閉づる方问に働く 力の大さが $F \sin \theta$ で表し 得る禁になし、圾驗片が共同 支点軸の周りに屈曲される坦 合のうのモーメントが常に $F \sin \theta \times L / \sin \theta=F L$ なる 如く權成した。この装置によ ると賞に一定与向に作用する 吅 2 を測定することにより

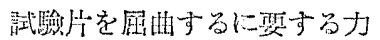
足知り得るから材料の諸性質

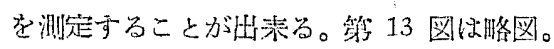

(山村)

\section{[130]}

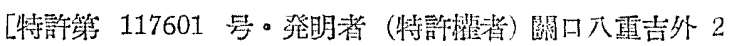

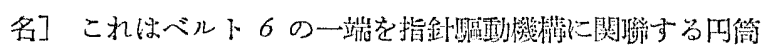

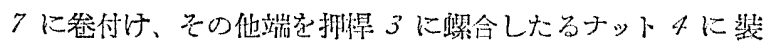
置した腕 5 に联付け、その取附点の抑倡に刘与る距離を調

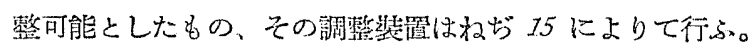
押掉 3 が押达まれると、ベルト6はばね13の力に抗して

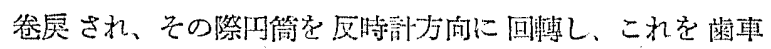

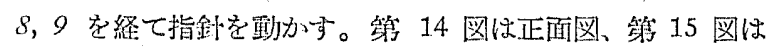
側断面図。

(山村)
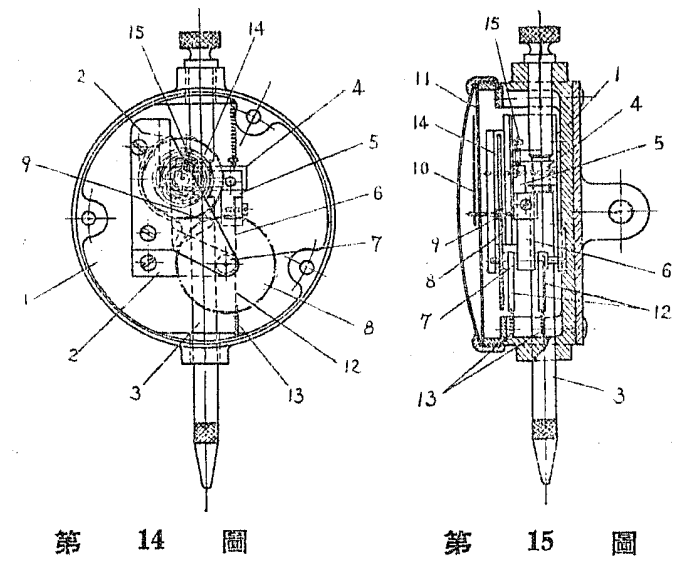

[131] 平乔盤における冬先振動防止装置

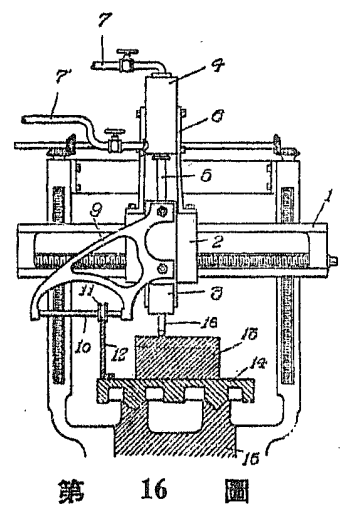

[特許第 117375 号 - 発明消 同部岩太椇外 1 名・(特敨權者)

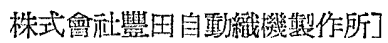
平戌盤に於て刀物取付合3の腕 9 に母型 12 に繤合すべき䅛動

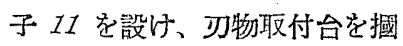
台 2 に上下に移動し得る椂に㙂 付ける。㨔台には简內にビスト ン8を有する円筒4を固定し、 そのピストンの同側に同一正力 の洗体を導入さ域る。ピストン

[第 39 兊籍 236 号 